\title{
HUBUNGAN TINGKAT DEPRESI DENGAN KEJADIAN INSOMNIA PADA LANJUT USIA DI GRIYA WERDHA JAMBANGAN SURABAYA
}

\author{
Nety Mawarda Hatmanti, Likha Muzdalifah \\ Universitas Nahdlatul Ulama Surabaya, nety.mawarda@unusa.ac.id
}

\begin{abstract}
Abstrak
Gangguan kesehatan yang dialami oleh lansia antara lain penurunan berfikir jernih dan kontak sosial sehingga lansia lebih memilih diam dan tidak menceritakan masalah yang dialaminya. Gangguan pada lansia tersebut berupa depresi ringan sebanyak 66,0\%. Tujuan penelitian ini untuk menganalisis hubungan tingkat depresi dengan kejadian insomnia. Desain penelitian adalah analitik dengan cross sectional. Populasi 53 responden dan besar sampel 47 responden. Jenis sampling adalah probability sampling dengan teknik simple random sampling. Variabel independen penelitian ini adalah tingkat depresi dan variabel dependen adalah kejadian insomnia. Instrumen pengumpulan data menggunakan kuesioner. Analisis data menggunakan uji statistik rank spearman $\alpha=0,05$. Hasil penelitian menggambarkan bahwa lansia sebagian besar $(55,3 \%)$ mengalami depresi sedang dansebagian besar $(53,2 \%)$ mengalami insomnia sedang. Hasil analisis membuktikan bahwa terdapat hubungan antara tingkat depresi dengan kejadian insomnia pada lansia $(\rho=0,000)$. Simpulan penelitian ini semakin tinggi tingkat depresi maka semakin banyak pula lansia yang mengalami insomnia. Hasil penelitian ini merekomendasikan kepada pengurus panti agar memberikan pendidikan kesehatan kepada lansia untuk melakukan aktivitas fisik, kegiatan keagamaan dan mengajarkan teknik relaksasi sehingga dapat menurunkan tingkat kejadian insomnia.
\end{abstract}

Kata kunci: Depresi, Insomnia, lansia

\begin{abstract}
Health problems that experienced by the elderly such as a decrease to think clearly, the decrease in social contacts that make elderly prefer silent and do not tell the problems that tend to buried themselves. Elderly who experienced mild depression as much as $66.0 \%$. The purpose of this study was to analyze the relationship of depression level with the incidence of insomnia. The design of this study was analytic with cross sectional. The population was 53 respondents and the sample size was 47 respondents. Using probability sampling method with Simple random sampling technique. The independent variable of this study is the level of depression and the dependent variable is the incidence of insomnia. Data processing using questionnaires. Data analysis using spearman rank test $\alpha=0,05$. The results showed that the elderly who suffered from depression were mostly (55.3\%) and insomnia were mostly $(53.2 \%)$. The results of the analysis prove that there is a relationship between depression level and insomnia incidence in elderly $(\rho=0,000)$. The conclusion of this study is the higher the level of depression, the more elderly people who experience insomnia. It is expected to nursing staff to provide health education, perform physical activities, religious activities and relaxation techniques to the elderly so as to reduce the incidence of insomnia.
\end{abstract}

Keywords: Depression, Insomnia, elderly

\section{PENDAHULUAN}

Orang yang berusia lanjut akan menjadi sangat rentan terhadap gangguan kesehatan, termasuk depresi yang disebabkan oleh stres dalam menghadapi perubahan-perubahan kehidupan yang berhubungan dengan apa yang disebut sebagai tahun emas. Perubahan kehidupan yang dimaksud antara lain adalah pensiun, penyakit atau ketidakmampuan fisik, penempatan dalam panti werdha, kematian 
pasangan dan kebutuhan untuk merawat pasangan yang kesehatannya menurun. Kematian keluarga yang dapat menimbulkan duka cita dan mengingatkan pada orang yang berusia lanjut akan usia mereka yang semakin bertambah (Nevid, J.S., Rathus S. A. \& Green B. 2015).

Gangguan kesehatan yang dialami oleh lanjut usia seperti mengalami penurunan untuk berfikir jernih dan sulit untuk memecahkan suatu masalah secara efektif, adanya penurunan kontak sosial yang membuat lanjut usia lebih memilih diam dan tidak menceritakan masalah yang dialaminya dan cenderung dipendam sendiri, sehingga mengakibatkan lanjut usia tertekan dan menyebabkan depresi.

Hasil penelitian Indrawati, S. E. Saputri, W. A. M. (2014) menjelaskan bahwa gangguan mental terbanyak pada lanjut usia yang tinggal di panti werdha adalah depresi yaitu sebesar 20,2\%. Gangguan depresi ditemukan kira-kira $25 \%$ pada lanjut usia yang ada di komunitas. Tingginya stressor dan peristiwa-peristiwa kehidupan yang tidak menyenangkan dapat menimbulkan kemungkinan lanjut usia mengalami kecemasan, kesepian, sampai pada tahap depresi. Tingkat depresi tetap lebih tinggi diantara lanjut usia penghuni rumah perawatan atau panti wredha. Hidup jauh dengan keluarga atau sanak saudara tentunya dapat menimbulkan perasaan kesepian, karena tidak ada lagi orangorang yang selama ini hidup bersama dan berbagi segala sesuatu.

Berdasarkan wawancara dengan perawat di Panti Griya Werdha Jambangan Surabaya, diperoleh informasi bahwa di Panti Griya Werdha Jambangan Surabaya terdapat 123 lanjut usia dengan laki-laki sebanyak 45 dan perempuan sebanyak 78 yang berusia 60 - 102 tahun. Kader Panti Griya Werdha Jambangan Surabaya juga mengatakan bahwa lanjut usia di panti tersebut mengeluhkan dirinya mengalami permasalahan seperti perubahan pada kondisi emosional, mudah tersinggung, sering melamun, merasa gelisah dengan penyakit yang dialaminya, gelisah karena memikirkan anaknya dan ketakutan akan kematian, perubahan dari kebiasaan tidur terlalu banyak atau terlalu sedikit, bangun lebih awal dari biasanya dan kesulitan untuk tidur kembali.

Menurut data WHO (World Health Organization) tahun 2014 diseluruh dunia jumlah orang lanjut usia diperkirakan sebanyak 629 juta dengan usia rata-rata 60 tahun dan diperkirakan pada tahun 2025 akan mencapai 1,2 milyar. Prevalensi depresi pada lanjut usia diseluruh dunia pada tahun 2014 berkisar 13,5\% dari seluruh jumlah lanjut usia dengan perbandingan wanita sebanyak $8,4 \%$ dan pria sebanyak 5,1\% (WHO, 2014). 
Berdasarkan data Depkes RI tahun 2014 di Indonesia prevalensi lanjut usia sebanyak 20.893.000 jiwa dengan jumlah lanjut usia yang mengalami depresi ringan sampai berat sebanyak 32\% (Depkes RI, 2014).

Data Provinsi Jawa Timur didapatkan, penduduk lanjut usia pada tahun 2014 diperkirakan mencapai angka 10,96\% dan tahun 2015 diperkirakan mencapai angka 11,5\% dan hingga 2020 akan meningkat menjadi 13,5\% (Nugroho, Sigit, Wahyu A. Yeni, Rachmawati, Mustari, Andhie Surya, 2014). Data di Kota Surabaya didapatkan jumlah penduduk lanjut usia tahun 2014 mencapai 350.000 jiwa (13\%) dari total jumlah penduduk di Surabaya (BPS Kota Surabaya, 2014).

Data awal yang didapatkan pada tanggal 21 Desember 2017 di Griya Werdha Jambangan Surabaya, bahwa jumlah lansia yang tinggal di panti tersebut sebanyak 123 lanjut usia. Hasil wawancara dengan 12 orang lansia didapatkan 5 orang mengatakan sulit tidur karena penyakit yang dialaminya seperti pusing, jantung, hipertensi dan asam urat, dan 7 orang mengatakan sulit tidur karena sering tidur disiang hari, memikirkan anaknya dan merasa ketakutan akan kematian.

Insomnia dapat disebabkan oleh adanya perubahan pada struktur kimia otak dan hormon otak, terdapat gangguan psikiatrik (depresi atau cemas). Ketika seseorang mendapat stressor, dimana terdapat peristiwa yang menyebabkan perubahan pada kehidupan seseorang sehingga orang tersebut terpaksa mengadakan adaptasi maka hormon stres akan meningkat dan menghambat produksi melatonin. Melatonin adalah suatu hormon yang mengatur ritme sirkadian (siklus 24 jam) di dalam tubuh kita. Akibat berkurangnya melatonin sehingga menyebabkan sulit tidur (Widya, 2010).

Lanjut usia berisiko tinggi mengalami insomnia akibat berbagai faktor diantaranya yaitu faktor fisik seperti sering kencing, kram betis, sakit gigi, atritis, akatisia. Faktor psikologis antara lain kecemasan, depresi, stres, keinginan yang tidak tercapai. Faktor lingkungan yang bising, seperti lingkungan lintasan pesawat terbang, suara TV yang keras. Gaya hidup yang tidak sehat juga dapat memicu munculnya insomnia. Kebiasaan mengkonsumsi alkohol, rokok, kopi/kafein (Susilo, Yekti \&Wulandari Ari, 2011).

Dampak insomnia dan depresi tersebut tidak bisa dianggap remeh, karena dapat menimbulkan kondisi yang lebih serius dan membahayakan kesehatan serta keselamatan. Oleh karena itu pentingnya memberikan pengetahuan tentang berbagai cara untuk mengurangi insomnia dan depresi, yaitu olahraga secara teratur pada pagi hari, tidur dalam lingkungan yang 
nyaman, mandi dengan air hangat 30 menit atau satu jam sebelum tidur, menghindari makan dan minum terlalu banyak menjelang tidur, melakukan aktifitas relaksasi secara rutin dan menghilangkan segala kekhawatiran yang mengganggu pikiran (Widya, 2010).

\section{METODE}

Desain penelitian yang digunakan adalah analitik dengan pendekatan cross sectional. Variabel penelitian meliputi variabel independen yaitu tingkat depresi dan variabel dependen adalah kejadian insomnia. Populasi penelitian adalah lanjut usia yang berusia 60 - 74 tahun sebesar 53 orang. Besar sampel penelitian yaitu 47 responden yang diambil secara probability sampling dengan teknik simple random sampling.

Data dianalisis dengan menggunakan uji statistik Rank Spearman, tingkat kemaknaan $\alpha=0,05$ dengan bantuan SPSS. Hasil analisis bila didapatkan $\rho<\alpha$ maka $\mathrm{H}_{0}$ ditolak artinya ada hubungan tingkat depresi dengan kejadian insomnia.

\section{HASIL}

\section{a. Data Umum}

Hasil penelitian pada data umum meliputi usia dan jenis kelamin lanjut usia di Griya Werdha Jambangan Surabaya.

1) Karakteristik lansia berdasarkan usia.
Karakteristik berdasarkan usia menurut organisasi kesehatan dunia World Health Organisation (WHO) ada 4 tahap lanjut usia meliputi: usia pertengahan (middle age) usia 45-59 tahun, lanjut usia (elderly) 60-74 tahun, lanjut usia tua (old) 75-90 tahun, usia sangat tua (very old) usia $\geq 90$ tahun.

Tabel 1 Data lansia berdasarkan tahapan lanjut usia di Griya Werdha Jambangan Surabaya tahun 2018.

\begin{tabular}{cccc}
\hline No & $\begin{array}{c}\text { Usia } \\
\text { (Tahun) }\end{array}$ & Frekuensi & $\begin{array}{c}\text { Persentase } \\
(\%)\end{array}$ \\
\hline 1 & $60-65$ & 22 & 46,8 \\
2 & $66-70$ & 17 & 36,2 \\
3 & $71-74$ & 8 & 17,0 \\
\hline & Total & 47 & 100 \\
\hline
\end{tabular}

Tabel 1 mengambarkan bahwa dari 47 lansia hampir setengahnya $(46,8 \%)$ berusia 60-65 tahun.

2) Karakteristik lansia berdasarkan jenis kelamin.

Karakteristik jenis kelamin menurut DepKes (2010) dibedakan menjadi 2 yaitu laki-laki dan perempuan. Berikut tabel jenis kelamin.

Tabel 2 Data lansia berdasarkan jenis kelamin di Griya Werdha Jambangan Surabaya tahun 2018.

\begin{tabular}{cccc}
\hline No & Jenis Kelamin & Frekuensi & $\begin{array}{c}\text { Persentase } \\
(\%)\end{array}$ \\
\hline 1 & Laki - laki & 17 & 36,2 \\
2 & Perempuan & 30 & 63,8 \\
\hline & Total & 47 & 100 \\
\hline
\end{tabular}

Tabel 2 menunjukkan bahwa dari 47 lansia sebagian besar $(63,8 \%)$ berjenis kelamin perempuan. 


\section{b. Data Khusus}

\section{1) Tingkat Depresi}

Data khusus berisi karakteristik lansia tentang tingkat depresi yang diuraikan dalam tabel berikut ini.

Tabel 3 Data lansia berdasarkan tingkat depresi di Griya Werdha Jambangan Surabaya tahun 2018.

\begin{tabular}{cccc}
\hline No & Tingkat Depresi & Frekuensi & $\begin{array}{c}\text { Persentase } \\
(\%)\end{array}$ \\
\hline 1 & Tidak Ada Depresi & 1 & 2,1 \\
2 & Depresi Ringan & 9 & 19,1 \\
3 & Depresi Sedang & 31 & 66,0 \\
4 & Depresi Berat & 6 & 12,8 \\
\hline & Total & 47 & 100 \\
\hline
\end{tabular}

Tabel 3 menunjukkan bahwa dari 47 lansia sebagian besar $(66,0 \%)$ mengalami depresi sedang sebanyak 31 orang.

2) Kejadian Insomnia

Data kejadian insomnia pada lanjut usia di Griya Werdha Jambangan Surabaya dapat dilihat pada tabel sebagai berikut.

Tabel 4 Data lansia berdasarkan Kejadian insomnia di Griya Werdha Jambangan Surabaya tahun 2018.

\begin{tabular}{cccc}
\hline No & Insomnia & Frekuensi & Persentase \\
\hline 1 & Tidak Ada & 1 & 2,1 \\
& Insomnia & & \\
2 & Insomnia Ringan & 15 & 31,9 \\
3 & Insomnia Sedang & 28 & 59.6 \\
4 & Insomnia Berat & 3 & 6,4 \\
\hline & Total & 47 & 100 \\
\hline
\end{tabular}

Tabel 4 menunjukkan bahwa 47 lansia sebagian besar $(59,6 \%)$ mengalami insomnia sedang sejumlah 28 orang.

3) Hubungan Tingkat Depresi Dengan Kejadian Insomnia pada Lanjut Usia di Griya Werdha Jambangan Surabaya.
Tabel 5 Tabulasi silang Hubungan Tingkat Depresi Dengan Kejadian Insomnia pada Lanjut Usia di Griya Werdha Jambangan Surabaya tahun 2018.

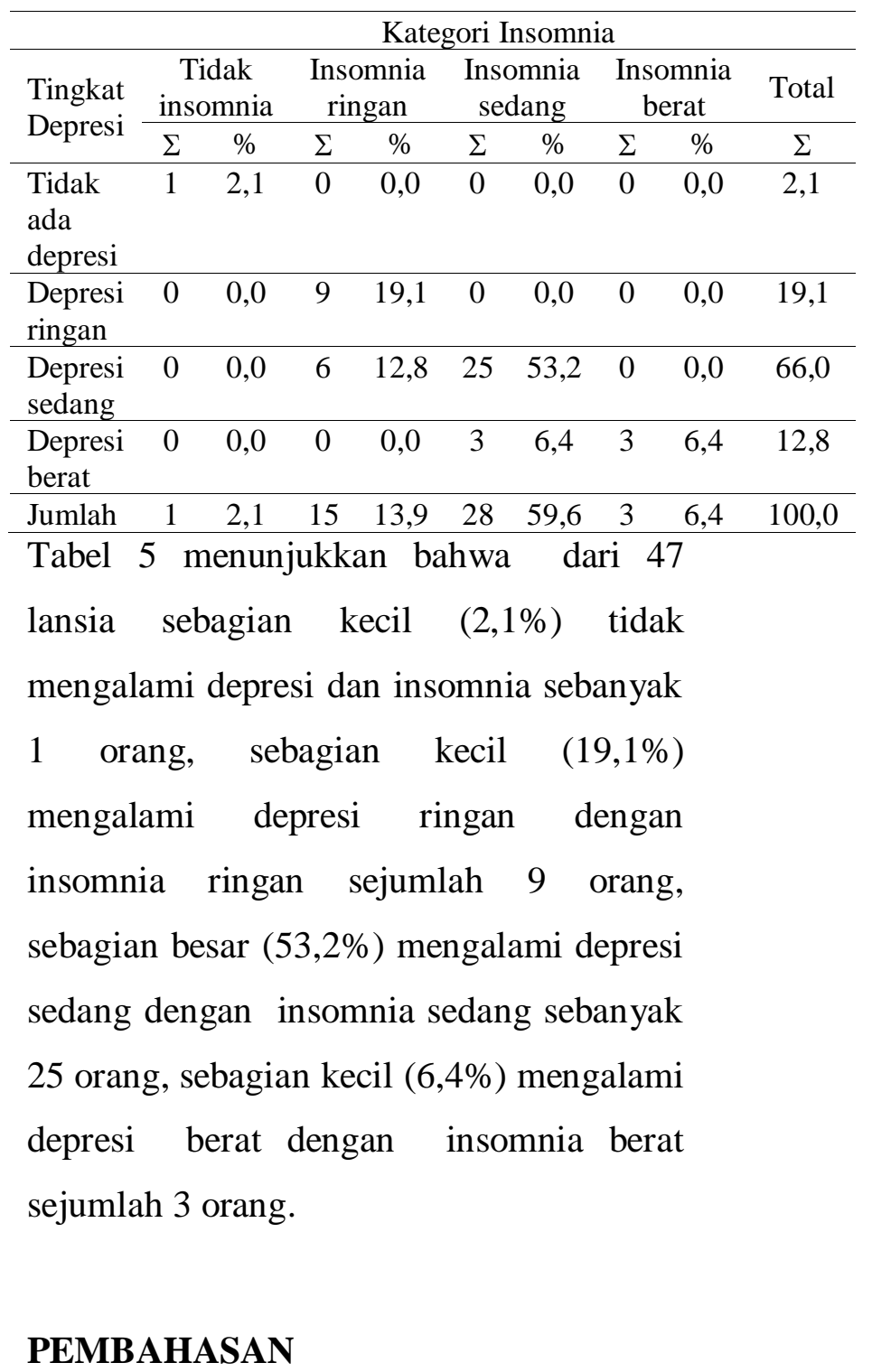

\section{Tingkat Depresi}

Hasil penelitian menunjukkan bahwa dari 47 lansia sebagian besar $(66,0 \%)$ mengalami tingkat depresi sedang. Hal ini diperkuat dengan data pada saat responden mengisi kuesioner pada pertanyaan yang bersifat favoreble. Hasil kuesioner menunjukkan bahwa 47 responden hampir 
seluruhnya $(77 \%)$ mengalami penurunan terhadap hobi, dikarenakan usia yang semakin menua dan keadaan fisik yang tidak memungkinkan untuk melakukan hobinya.

Lansia sebagian besar (62\%) merasa bahwa kehidupannya kosong, dikarenakan lansia tidak memiliki pandangan hidup kedepannya yang hanya bergantung pada panti. Lansia sebagian besar $(60 \%)$ merasa bahwa kehidupannya bosan yang dikarenakan lansia merasa bahwa mereka hidup didalam panti terlalu dibatasi sebab mereka mengeluh tidak bisa jalan-jalan keluar hanya boleh didalam panti saja, sedangkan beberapa lansia ingin jalanjalan keluar untuk mengetahui dunia luar.

Lansia sebagian besar (55\%) takut akan sesuatu yang buruk menimpa dirinya karena lansia takut akan kematian jika suatu saat terjadi kepadanya. Lansia sebagian besar (53\%) mengalami tidak berdaya karena dirinya merasa sakitsakitan dan tidak bertenaga.

Lansia sebagian besar (64\%) lebih suka tinggal di panti karena mereka merasa lebih terurus dari pada di rumah.Lansia hampir seluruhnya (79\%) mengalami penurunan daya ingat karena semakin tua usia semakin lemah daya pikir lansia tersebut.

Lansia hampir setengahnya (45\%) merasakan bahwa hidupnya tidak berharga hal ini karena tidak sedikit yang meremehkan mereka karena usianya yang sudah tua yang dianggap mereka tidak penting dalam hal apapun. Lansia sebagian besar $(51 \%)$ bahwa dirinya tidak ada harapan, mereka merasa bahwa diusianya yang sudah tua ini mereka sakit-sakitan dan sudah pasrah terhadap penyakit yang dialaminya.

Lansia hampir seluruhnya (83\%) bahwa keadaanya lebih buruk daripada orang lain, hal ini dikarenakan pemikiran lansia yang sudah semakin menua dan menganggap bahwa dirinya sudah tidak berdaya dan lemah. Lansia hampir seluruhnya (83\%) mengalami ketidak puasan dalam hidupnya yang disebabkan mereka terlalu banyak berpikir bahwa kehidupan yang dialaminya saat ini tidak sesuai dengan harapan mereka, dimana ketika seorang lansia berusia lanjut mengharapkan hidupnya tenang tidak ada beban pikiran tetapi sebaliknya di usia mereka yang tua seperti ini mereka banyak berpikir seperti sanak keluarga yang meninggalkan mereka, penyakit yang diderita oleh lansia, penurunan daya pikir yang membuat mereka sulit untuk berpikir jernih dan memecahkan suatu masalah ketika terdapat masalah didalam panti tersebut.

Lansia sebagian besar $(60 \%)$ masih memiliki semangat hidup sebab mereka masih memiliki keluarga meskipun 
keluarga mereka tidak perduli terhadap keadaan lansia saat ini. Lansia sebagiaan besar $(53 \%)$ merasa bahagia karena mereka hidup terurus didalam panti. Lansia hampir seluruhnya (70\%) memiliki perasaan sedih karena jika teringat tentang keluarganya mereka masih merindukan dan berharap dijeguk oleh keluarganya. Lansia sebagian besar (57\%) mengalami semangat yang tinggi dalam kehidupan sehari-hari.

Tingkat depresi yang terjadi pada lansia yang berada dipanti sering kali tidak sesuai dengan kebutuhan dan kemauan, dimana ketika kebutuhan pada lansia bisa terpenuhi sepenuhnya akan tetapi kemauan yang bermacam-macam belum terpenuhi seperti menginginkan adanya kebebasan untuk jalan-jalan diluar panti, tidak diremehkan oleh teman-temannya, dan tidak dianggap lemah. Biasanya depresi tersebut muncul seiring dengan usia yang lanjut dimana kondisi fisik maupun psikis mulai mengalami penuaan, sehingga lansia membutuhkan kasih sayang serta perhatian untuk menurunkan tingkat depresi tersebut. Jeffry (2013) menjelaskan bahwa depresi pada lansia akan berkaitan dengan proses penuaan yang terjadi pada diri lansia. Pada fase tersebut akan terjadi perubahan fisik dan mental yang mengarah ke penuaan. Proses menjadi tua menghadapkan lansia pada salah satu tugas yang sulit dalam perkembangan hidup manusia. Kehidupan individu ada periode-periode kritis yang berpengaruh pada perkembangan mental yang dapat mempengaruhi depresi pada masa yang akan datang.

Hasil penelitian ini juga menunjukkan bahwa dari 47 lansia hampir setengahnya $(46,8 \%)$ berusia $60-65$ tahun. Lansia yang berusia 60-65 tahun dapat mengalami tingkat depresi ringan, sedang dan berat, diantara ketiga tingkat depresi tersebut lansia lebih banyak mengalami depresi sedang dengan persentase $(17,0 \%)$, kemudian pada lansia yang berusia 66-70 tahun mengalami penurunan terhadap depresi ringan dan berat akan tetapi mengalami peningkatan pada depresi sedang dengan persentase $(21,3 \%)$. Lansia yang berusia 71-74 tahun menggalami penurunan terhadap tingkat depresi sedang dengan persentase $(14,9 \%)$ dan mengalami penurunan terhadap tingkat depresi ringan dan tidak mengalami depresi berat.

Usia lanjut merupakan usia dimana cara berpikir, memahami, menerima atau merespon suatu hal telah mengalami penurunan. Oleh karena itu sering dijumpai banyak lansia yang cerewet, mudah tersinggung, emosional, kekanak-kanakan dan sebagainya, sehingga mereka rentan terkena depresi. Menurut Susanto (2014) depresi paling banyak dijumpai pada usia 40-50 tahun dan kondisinya semakin memburuk pada lanjut usia karena hal 
tersebut berkaitan dengan kematangan kepribadian yang menurun pada usia lanjut.

Faktor lain yang mempengaruhi tingkat depresi yaitu jenis kelamin. Hasil penelitian menunjukkan bahwa 47 lansiasebagian besar $(63,8 \%)$ memiliki jenis kelamin perempuan. Pada jenis kelamin perempuan hampir setengahnya $(38,3 \%)$ mengalami depresi sedang. Akan tetapi jenis kelamin laki-laki dan perempuan memiliki persamaan nilai pada depresi berat. Kondisi tersebut dapat dijelaskan bahwa hal ini disebabkan oleh pola pikir perempuan lebih cenderung menggunakan emosional daripada rasional, atau permasalahan yang sebenarnya sederhana bagi perempuan bisa menjadi rumit. Sifat egois dimasa lansia juga sering muncul, berbagai permasalahan yang di tanggapi dengan reaksional dapat mengakibatkan depresi. Hasil penelitian Lindia Prabhaswati (2015) tentang gambaran kejadian depresi pada lansia di Bali menjeaskan angka depresi pada lansia perempuan ditemukan lebih tinggi, alasannya karena adanya perbedaan yang melibatkan faktor hormonal, perbedaan stressor psikososial bagi perempuan.

\section{Kejadian insomnia}

Hasil penelitian menunjukkan bahwa dari 47 lansia sebagian besar $(59,6 \%)$ mengalami insomnia sedang. Hal ini dapat dilihat saat mengisi kuesioner tentang kejadian insomnia sebagian besar (52\%) lansia tidur dalam sehari selama 5 jam 30 menit - 6 jam 29 menit sedangkan untuk normal tidur lansia adalah lebih dari 6,5 jam.

Lansia sebagian besar (72\%) terkadang mengalami mimpi yang menyenangkan, disebabkan karena dalam hidup keadaan lansia tidak selalu buruk. Lansia sebagian besar $(57 \%)$ mengalami tidur sedang dan sulit terbangun yang dikarenakan lansia ketika awal memasuki tidur pikirannya tidak tenang.

Lansia sebagian besar (64\%) mengawali tidur antara 15 - 29 menit karena lansia merasakan sakit fisik didaerah kakinya yang menyebabkan kesulitan untuk masuk tidur. Lansia sebagian besar (67\%) terbangun ketika malam hari 1 - 2 kali karena meskipun tertidur tetapi lansia tetap terfikirkan akan hal yang membuat dia depresi.

Lansia sebagian besar (67\%) sulit untuk tidur kembali setelah tidur antara $15-29$ menit karena jika sudah bangun maka lansia akan teringat lagi akan masalah yang dialaminya. Lansia sebagian besar (64\%) bangun dini hari dan satu jam bangun lebih awal dan tidak dapat tidur lagi dikarenakan lansia terlalu memikirkan masalah yang dihadapinya sehingga membuat lansia tidak dapat mengawali tidur. 
Lansia sebagian besar (72\%) mengalami perasaan tidak segar saat terbangun karena ketika lansia tidur tidak sepenuhnya terlelap dikarenakan banyak masalah yang menganggu dipikirannya.

Kejadian insomnia pada lansia sering diperburuk dengan adanya berbagai gangguan psikososial atau penyakit yang diderita lansia. Gangguan psikososial umumnya terjadi berkaitan dengan kehilangan pasangan, terjadinya permasalahan dengan teman, ketidak nyamanan pada tempat tidur dan lingkungan. Sedangkan yang disebabkan oleh penyakit seperti nyeri sendi, osteoporosis, asam urat. Jika penyebab utama tidak diatasi maka gangguan insomnia pada lansia tidak akan pernah teratasi.

Yekti Susilo (2011) menjelaskan bahwa insomnia merupakan hal umum yang terjadi pada lansia berkaitan dengan menurunnya fungsi organ tubuh dan psikologis, insomnia pada lansia ditandai dengan gejala-gejala sulit untuk mengawali tidur, sering terbangun dan mengawali bangun tidur.

\section{Hubungan Tingkat Depresi dengan} Kejadian Insomnia pada Lanjut Usia

Hasil penelitian uji statistik rank spearman dengan tingkat signifikan $\alpha=0,05$ didapatkan nilai $\rho(0,000)$ dan $\alpha=0,05$. Berarti ada Hubungan tingkat depresi dengan kejadian insomnia pada lanjut usia di Griya Werdha Jambangan Surabaya.

Hasil penelitian tersebut menunjukkan bahwa tingkat depresi berpengaruh secara signifikan terhadap kejadian insomnia. Hal ini berarti ketika lanjut usia mengalami penurunan fisik dan masalah psikologis maka lansia akan susah mengawali tidur bahkan cenderung susah tidur yang dapat mengakibatkan terjadinya insomnia. Peran pengurus panti dapat membantu untuk mengatasi tingkat depresi sehingga kejadian insomnia akan menurun.

Rafknowledge (2014) menjelaskan bahwa stres psikologis yang dialami oleh lansia dapat menyebabkan insomnia yang mempengaruhi konsentrasi, meningkatkan risiko kesehatan dan dapat merusak fungsi sistem imun. Adanya hubungan tingkat depresi dengan kejadian insomnia pada lansia dan yang mengalami depresi berat cenderung mengalami insomnia berat. Hal ini dapat terjadi akibat dari depresi yang dialami lansia mengganggu pikiran, sehingga sering terbangun di malam hari dan sulit tidur kembali. Depresi yang mereka alami juga berdampak pada penyakit fisik seperti sakit kepala, darah tinggi dan asam urat yang dapat menyebabkan terjadinya insomnia pada lansia.

Bagi lansia yang mengalami depresi sedang dengan insomnia ringan disebabkan 
karena faktor pemicu depresi yang terjadi cukup menganggu pikiran dan aktivitas lansia seperti status kesehatan yang semakin menurun serta kurang perhatian dari keluarga. Tentunya masalah ini akan menjadi beban pikiran bagi para lansia yang menyebabkan mereka tidak bisa istirahat dan tidur dengan tenang (Rafknowledge, 2014).

Lansia yang mengalami depresi berat dengan insomnia sedang dikarenakan faktor emosional dimana terjadinya kegelisahan yang mendalam, kemarahan yang tidak terkendali, situasi sosial yang tidak berpihak. Hal ini dapat menyebabkan lansia sulit untuk tidur, mempertahankan tidur dan bangun lebih dini yang dapat menyebabkan gangguan dalam tidurnya dan mengalami depresi terhadap lansia (Rafknowledge, 2014).

\section{SIMPULAN DAN SARAN}

\section{Simpulan}

a. Lanjut usia sebagian besar mengalami depresi sedang di Griya Werdha Jambangan Surabaya.

b. Lanjut usia sebagian besar mengalami insomnia sedang di Griya Werdha Jambangan Surabaya.

c. Tingkat Depresi mempunyai hubungan yang signifikan dengan Kejadian Insomnia pada Lanjut Usia di Griya Werdha Jambangan Surabaya.

\section{Saran}

a. Bagi peneliti selanjutnya

Hasil penelitian ini menjadi acuan untuk peneliti berikutnya yang berkaitan dengan hubungan antara tingkat depresi dengan pola hidup yang tidak sehat pada lanjut usia.

b. Bagi Griya Werdha

Hasil penelitian ini merekomendasikan kepada Panti agar memberikan pengetahuan baik melalui pelatihan maupun pendidikan nonformal bagi para kader-kadernya sehingga menjadi bekal untuk memberikan pendidikan bagi para anggota lansia akan pentingnya perawatan kesehatan fisik dan psikis, khususnya penderita depresi dan insomnia.

c. Bagi Lanjut Usia

Diharapkan lanjut usia yang berada di Griya Werdha Jambangan Surabaya melakukan aktivitas fisik, kegiatan keagamaan, dan menjaga pola makan secara teratur, sehingga lansia terhindar dari depresi dan risiko kejadian insomnia.

\section{DAFTAR PUSTAKA}

Arikunto, S. (2013).Prosedur Penelitian: Suatu Pendekatan Praktik. Jakarta, Pt Renika Cipta

Badan Pusat Statistika Kota Surabaya. (2014). Surabaya Dalam Angka Surabaya In Figures. Surabaya, Badan Pusat Statistika Kota Surabaya

Badriyah, Siti. (2009). Lanjut Usia Dan Keperawatan Gerontik. Jakarta, Medical Book 
Colbert, Don. (2011). Depresi Cara Mencegah dan Mengatasinya. Bali, Udayana University Press

Depkes RI (2014). Peraturan Menteri Kesehatan Republik Indonesia Nomor 155/Menkes/Per/I/2014 Tentang Penggunaan Kartu Menuju Sehat (KMS) Bagi Lansia. Diakses dari www.gizikia.depkes.go.id pada tanggal 29 November 2017. Jam 21.00 WIB

Dewi, Sofia, Rhosma. (2014). Buku Ajar Keperawatan Gerontik. Yogyakarta, Deepublis

Hadi, Pranaka, Kris. (2010). Buku ajar boedhi darmojo GERIATRI. Jakarta, Fakultas Kedokteran UNIVERSITAS INDONESIA

Indrawati, S. E. Saputri, W. A. M. (2014). Hubungan Antara Dukungan Sosial dengan Depresi Pada Lanjut Usia yang Tinggal di Panti Wredha Wening Wardoyo Jawa Tengah. Jurnal Psikologi Undip. Vol. 9, No.1, April 2011. Diakses dari http; Google Scholar.com.pada 6 oktober 2017. Jam 19.00 WIB

Kementrian kesehatan RI. (2015). Infodatin: Pusat Data dan Informasi Kementrian RI, Situasi dan Analisis Lanjut Usia. Diakses dari http://www.depkes.go.id. Pada tanggal 13 september 2017. Jam 16.00

Lindia prabhaswati. (2015). Gambaran Kejadian Depresi Pada Lanjut Usia Di Wilayah Kerja Puskesmas Petang I Kabupaten Badung Bali. Diakses dari http: Google Scholar.com. pada tanggal 10 Juli 2018. Jam 20.00 WIB

Maas, L. Meridean. (2011). Asuhan Keperawatan Geriatrik: Diagnosis NANDA, Kriteria Hasil NOC, \& Intervensi NIC. Jakarta, EGC

Maryam, Siti dan Jubaedi, Ahmad. (2009). Mengenal Usia Lanjut Dan Perawatannya. Jakarta, Salemba Medik
Nevid, J.F. (2014). Psikologi Abnormal. Jakarta, Erlangga

Nevid, J.S., Rathus S. A. \& Green B. (2015). Psikologi Abnormal. Edisi kelima, Jilid Dua. Jakarta: Erlangga.

Nugroho, Sigit, Wahyu A. Yeni, Rachmawati. Mustari, Andhie Surya (2014). Statistik Penduduk Lanjut Usia. Jakarta, Badan Pusat Statistik

Nursalam. (2013). Metode Penelitian Ilmu Keperawatan Pendekatan Praktis Edisi 3. Jakarta, Salemba Medika

Perry \& Potter. (2008). Fundamental Keperawatan. Jakarta: Salemba Medika.

Priyoto. (2015). NIC Dalam Keperawatan Gerontik. Jakarta, Salemba Medika

Purnomo, Windhu. (2013). Pengantar Metodologi Penelitian Kuantitatif. Surabaya, FKM Unair

Rafknowledge. (2014). Insomnia dan Gangguan Tidur. Elex Media Komputindo. Jakarta

S. Tamher \& Noorkasiani. (2011). Kesehatan Usia Lanjut Dengan Pendekatan Asuhan Keperawatan. Jakarta, Salemba Medika

Saputra, Lyndon. (2013). Catatan Ringkas Kebutuhan Dasar Manusia. Tangerang Selatan, Binar Aksara

Sugiyono. (2011). Metode penelitian kuantitatif, kualitatif dan $R \& D$. Bandung, Avabeta

Susilo, Yekti dan Wulandari, Ari (2011). Cara Jitu Mengatasi Insomnia. Yogyakarta, Maria

WHO. (2014). Diarrhoea: The handbook of psychological assesment. Diakses dari www.who.com. Pada tanggal 12 Oktober 2017. Jam 13.000 WIB

Widya, (2010). Mengatasi Insomnia. Jogjakarta, Katahati 